\title{
Perawatan Teknik Begg Pada Maloklusi Klas I Dengan Kaninus Impaksi dan Insisivus Lateral Agenesis
}

\author{
Kristina Wijaya Gunawan*, Wayan Ardhana**, dan Christnawati** \\ * Program Studi Ortodonsia PPDGS Fakultas Kedokteran Gigi Universitas Gadjah Mada \\ ** Bagian Ortodonsia, Fakultas Kedokteran Gigi Universitas Gadjah Mada \\ *J Denta no 1 Sekip Utara Yogyakarta;, e-mail: kristinawijayadrg@gmail.com
}

\begin{abstract}
ABSTRAK
Impaksi kaninus maksila sering dijumpai pada sisi palatal daripada labial. Agenesis adalah anomali pertumbuhan akibat tidak ada satu atau lebih benih gigi. Laporan kasus ini bertujuan memaparkan kemajuan perawatan kasus Maloklusi klas I dengan kaninus impaksi dan insisivus lateral agenesis menggunakan alat cekat teknik Begg. Seorang pasien usia 20 tahun datang mengeluhkan gigi-gigi depan atas dan bawah yang berjejal sehingga mengganggu penampilan. Perawatan bertujuan untuk koreksi Maloklusi Angle klas I tipe dentoskeletal dengan deepbite, crossbite gigi 25 terhadap 35, pergeseran midline dental maksila dan mandibula ke kanan sebesar 2,5 mm dan 3,0 mm, 13 impaksi vertikal pada sisi labial, 42 agenesis, dan edentulous parsial regio 36 . Koreksi dilakukan dengan pencabutan 14, 25, pemanfaatan ruang bekas pencabutan 36 dan exposure gigi kaninus yang impaksi. Tahap pertama teknik Begg adalah leveling, unraveling, dan bite opening, diikuti dengan koreksi midline dan penutupan sisa ruang bekas pencabutan. Kesimpulan: perawataanortodontik menggunakan teknik Begg yang dilakukan simultan dengan exposure kaninus impaksi labial dengan closed eruption technique dapat memberikan hasil yang memuaskan.

Maj Ked Gi. Juni 2013; 20(1): 105 - 111
\end{abstract}

Kata Kunci: exposure, kaninus impaksi, insisivus lateral agenesis, teknik Begg

\begin{abstract}
Treatment for Class I Malocclusion with Impacted Canine and Agenesis Lateral Incisor Using Begg Technique. Maxillary canine impaction occurs commonly on the palatal than labial side. Agenesis is a developmental anomaly condition because of the absence of one or more tooth buds. This case report aims to explain the treatment progress of class I malocclusion with impacted canine and agenesis lateral incisor using fixed appliance through Begg technique. A 20-year-old female patient complained about her upper and lower anterior dental crowding that disturbed her appearance. The treatment aims to correct the Angle class I malocclusion dentoskeletal types with deepbite, crossbite 25 to 35, maxillary and mandibulary dental midline shift to the right by $2.5 \mathrm{~mm}$ and $3.0 \mathrm{~mm}, 13$ labially vertical impacted, 42 agenesis, and partial edentulous 36 . The correction was obtained through extraction 14 and 25, and the use of former space from extraction 36 and exposure of impacted canine. The first step of treatment using Begg technique is to leveling, unraveling, and bite opening. The second step is midline correction and space closure. Finally, it can be concluded that orthodontic treatment using Begg technique which is done simultaneously and exposure of labial-canine impaction with closed eruption technique can give satisfactory results.
\end{abstract}

Maj Ked Gi. Juni 2013; 20(1): 105 - 111.

Key Words: exposure, impacted canine, agenesis lateral incisor, Begg technique

\section{PENDAHULUAN}

Maloklusi adalah penyimpangan letak gigi dan atau malrelasi lengkung gigi atau rahang diluar rentang kewajaran yang dapat diterima atau keadaan yang menyimpang dari oklusi normal. ${ }^{1.2}$ Berbagai factor yang mempengaruhi oklusi adalah 1) ukuran maksila dan mandibula, 2) relasi maksila dan mandibula, 3) jumlah, ukuran, dan morfologi gigi, serta 4) morfologi dan sifat jaringan lunak. ${ }^{3}$ Kelainan pada komponen tersebut serta interaksinya dapat menyebabkan maloklusi. ${ }^{1}$
Maloklusi Angle klas I merupakan suatu kondisi oklusi molar pertama dengan posisi tonjol mesiobukal molar pertama maksila berkontak pada groove bukal molar pertama mandibula. ${ }^{3}$ Pola skeletal maloklusi Angle klas I dapat klas I, kelas II atau kelas III ringan. Maloklusi klas I disertai berbagai macam malrelasi, maloklusi gigi individual, dan anomali gigi yang disebabkan oleh diskrepansi ukuran gigi dan atau lengkung gigi. ${ }^{1}$ Tidak adanya satu atau beberapa gigi dalam rongga mulut dapat disebabkan oleh impaksi atau agenesis. 
Impaksi kaninus maksila terjadi kurang dari $2 \%$ populasi dan sering terjadi pada perempuan. ${ }^{4,5}$ Kurang lebih sepertiga kasus kaninus maksila impaksi mempunyai lokasi di labial dan lainnya di palatal. ${ }^{6}$ Impaksi pada sisi palatal berkaitan dengan berbagai anomali dental seperti anomali insisivus lateral atas, aplasia, dan impaksi gigi-gigi yang lain. ${ }^{7}$ Impaksi kaninus pada sisi labial menunjukkan adanya defisiensi panjang lengkung maksila. ${ }^{5}$ Resopsi akar gigi tetangga, waktu perawatan yang lebih lama, dan hasil yang kurang memuaskan secara estetis berkaitan dengan kaninus maksila impaksi. ${ }^{8.9}$

Diagnosis impaksi kaninus didasarkan pada pemeriksaan klinis dan radiografis. Berbagai jenis pemeriksaan radiografis seperti film oklusal, panoramik, dan sefalogram lateral dapat membantu evaluasi posisi kaninus, tetapi pada umumnya digunakan film periapikal. ${ }^{6}$ Dua film periapikal diambil pada objek yang sama dengan angulasi horisontal cone diubah pada pengambilan yang kedua. Apabila objek bergerak berlawanan arah dengan pergeseran cone, gigi impaksi berada pada posisi bukal/ labial dan jika sebaliknya maka gigi berada pada sisi palatal, dikenal sebagai teknik shift sketch. ${ }^{9}$

Perawatan kaninus impaksi bervariasi tergantung pada keadaan klinis. Ekstraksi kaninus desidui, ekspansi lengkung gigi atau area lokal, exposure dan atau ekstraksi dan ekspansi bertujuan untuk memberi ruang erupsi. ${ }^{5}$ Terdapat 3 teknik exposure kaninus yaitu excisional uncovering, apically positioned flap, dan closed eruption technique. Pemilihan teknik exposure berdasarkan 4 kriteria yaitu 1) posisi labiolingual mahkota kaninus, 2) posisi vertikal kaninus impaksi relatif terhadap batas mukogingiva, 3) jumlah gingiva pada area kaninus impaksi, dan 4) posisi mesiodistal mahkota kaninus. Perawatan dilanjutkan dengan tarikan secara mekanika ortodontik erupsi gigi menyerupai normal dan memposisikan gigi dalam lengkung gigi sehingga diperoleh hubungan gingiva labial yang normal. ${ }^{9}$

Agenesis merupakan suatu kondisi anomali pertumbuhan berupa tidak adanya satu atau lebih benih gigi. Agenesis terjadi pada $2 \%-10 \%$ populasi. Agenesis satu atau lebih gigi molar ketiga terjadi pada
$20 \%$ populasi, sedangkan 1,6\%-9,6\% terjadi pada gigi selain molar ketiga. Premolar dan insisivus lateral atas sering mengalami agenesis, namun agenesis insisivus lateral mandibula, kaninus, premolar pertama dan molar pertama jarang terjadi. ${ }^{10}$

Perawatan ortodontik bertujuan memperbaiki estetik dan fungsi regio orofasial serta kestabilan hasil perawatan melalui penggunaan alat ortodontik. ${ }^{3,11,12}$ Pada kasus dengan keterlibatan skeletal atau diperlukan pembedahan gigi diperlukan penanganan interdisipliner dengan bagian lain seperti Bedah Mulut. Maloklusi Angle klas I dapat dirawat dengan alat cekat teknik Begg. Perawatan teknik Begg menggunakan kawat busur bulat dan braket yang menghasilkan titik kontak tunggal sehingga gigi bergerak secara tipping. Oleh karena itu, kesejajaran gigi dapat dicapai secara cepat pada tahap awal perawatan, namun diperlukan root paralleling dan torquing pada tahap akhir. Kawat busur dilengkapi dengan loop vertikal, circle hook di mesial braket gigi kaninus, anchorage bend, dan berbagai alat tambahan seperti rotating spring, uprighting spring, dan torquing arch. Pengurangan overbite disebabkan gerakan resiprokal gigi molar mandibula dan anchorage bend sehingga mengakibatkan gaya intrusi gigi-gigi anterior. Komponen gaya vertikal elastik intermaksiler klas II membantu memberikan elevasi gigi molar mandibula sehingga menambah gaya depresi pada gigi insisivus mandibula dan intrusi gigi anterior maksila. ${ }^{13,14}$

Artikel ini bertujuan memaparkan kemajuan perawatan kasus Maloklusi klas I dengan kaninus impaksi dan insisivus lateral agenesis menggunakan alat cekat teknik Begg.

\section{STUDI KASUS}

Pasien perempuan 20 tahun datang ke klinik Ortodonsia RSCM Prof. Soedomo dengan keluhan gigi-gigi depan atas dan bawah berjejal sehingga mengganggu penampilan. Riwayat gigi geligi pasien pada masa gigi susu mengalami rampan karies, masa gigi bercampur pernah mengalami persistensi pada regio anterior kanan mandibula, dan masa gigi permanen pernah mencabutkan molar pertama kiri mandibula. Pemeriksaan klinis menunjukkan gigi- 

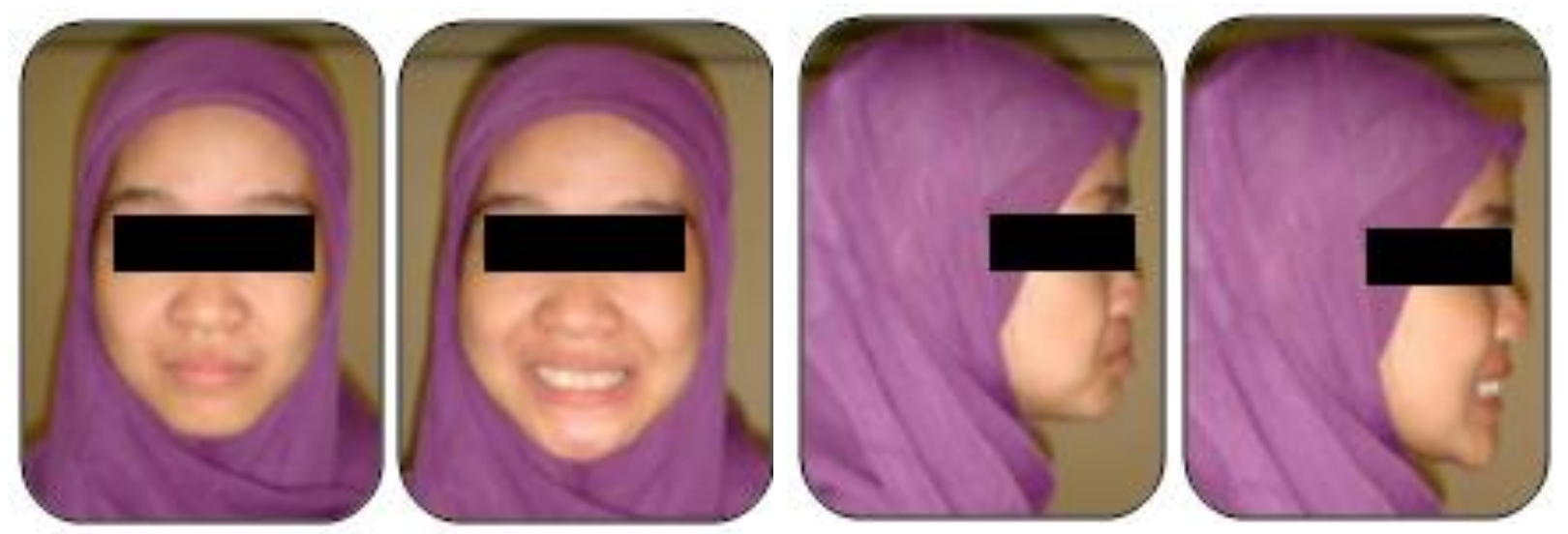

Gambar 1. Foto ekstraoral pasien sebelum perawatan

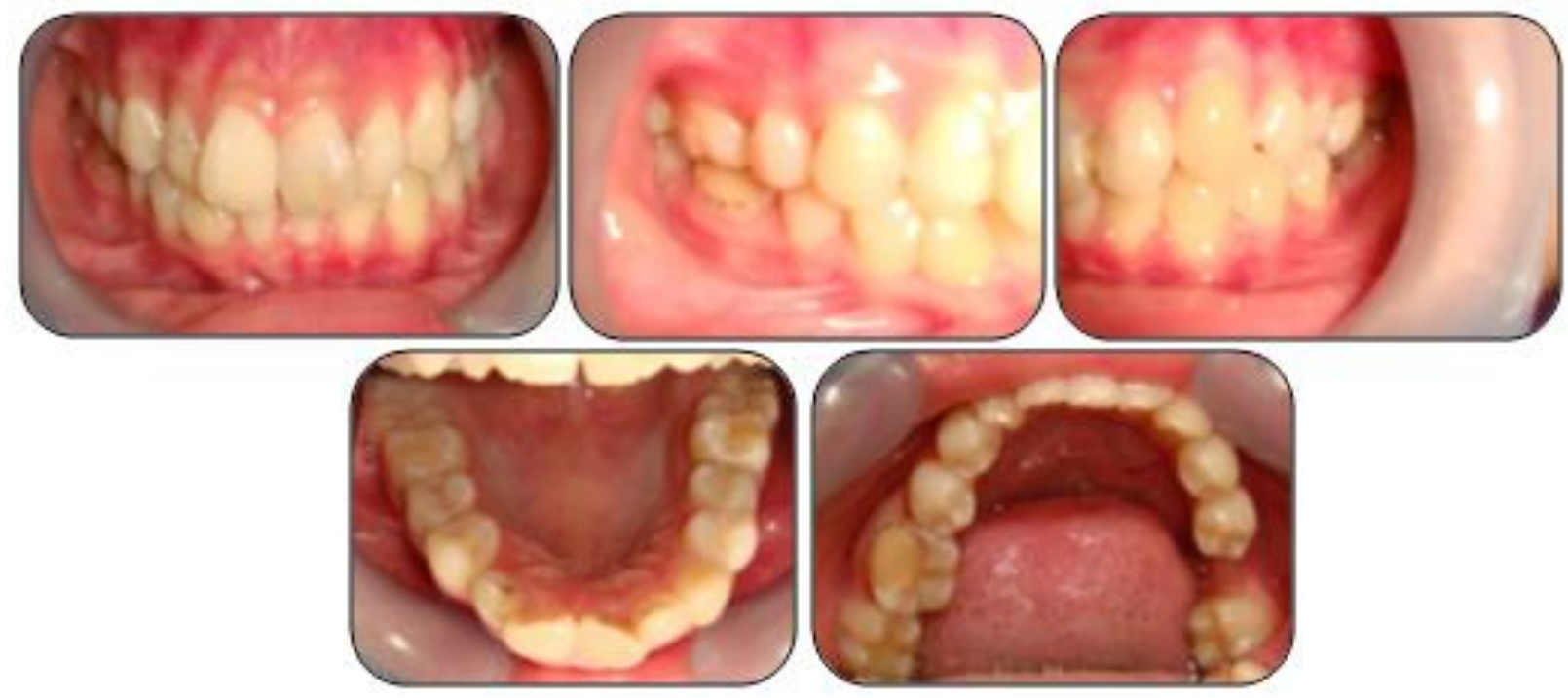

Gambar 2. Foto intraoral pasien sebelum perawatan

gigi maksila dan mandibula berjejal, tidak terdapat gigi kaninus kanan maksila dan insisivus lateral kanan mandibula, molar pertama kiri mandibula telah dicabut, serta garis tengah dental maksila dan mandibula bergeser ke kanan sejauh 2,5 mm dan 3,0 $\mathrm{mm}$. Pemeriksaan model studi menunjukkan relasi molar pertama kanan klas I Angle. Overjet 3,00 $\mathrm{mm}$, overbite $5,00 \mathrm{~mm}$ (deepbite) dan crossbite pada regio posterior kiri (gambar 1 dan gambar 2). Riwayat keluarga pasien memiliki ayah dengan ukuran gigi besar-besar dan susunan berjejal sehingga terdapat faktor genetik pada susunan gigi geligi.
Pemeriksaan radiografi menunjukkan adanya gigi kaninus kanan maksila impaksi vertikal pada sisi labial dan gigi insisivus lateral kanan mandibula agenesis serta hubungan skeletal klas I dengan dental normal (gambar 3 dan tabel 1). Diagnosis kasus pasien adalah maloklusi Angle klas I tipe dentoskeletal disertai deepbite, crossbite gigi 25 terhadap 35, pergeseran midline dental maksila dan mandibula ke kanan sebesar 2,5 mm dan 3,0 $\mathrm{mm}$, gigi 13 impaksi vertikal pada sisi labial, gigi 42 agenesis, dan edentulous parsial regio 36. 


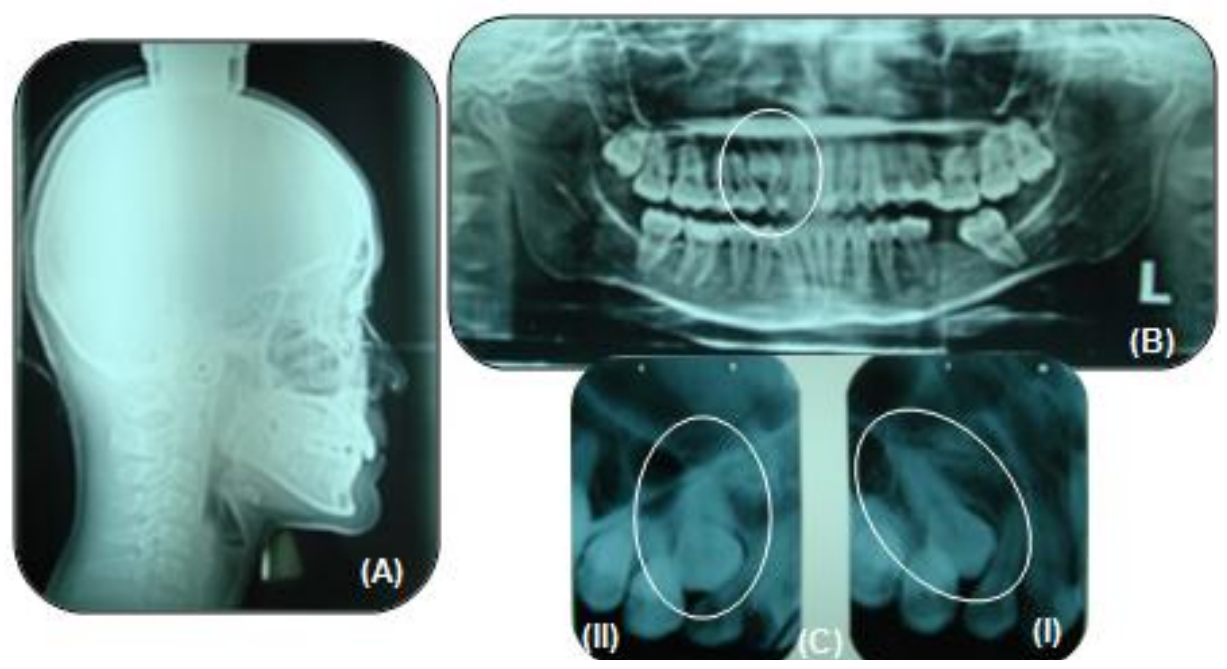

Gambar 3. Radiograf sebelum perawatan (A) Sefalogram; (B) OPG, (C) Shift sketch

Tujuan perawatan adalah menarik gigi kaninus impaksi untuk erupsi, mengoreksi crowding, pergeseran midline dental maksila, deepbite, dan mempertahankan relasi molar pertama kanan klas 1 . Rencana perawatan dilakukan perawatan alat cekat teknik Begg dengan pencabutan gigi 14 dan 25, exposure gigi 13 impaksi, dan pemanfaatan ruang bekas pencabutan gigi 36. Berdasarkan perhitungan determinasi lengkung dan set up model Kesling masih dibutuhkan ruang sebesar 13,20 mm untuk maksila dan terdapat sisa ruang $2,60 \mathrm{~mm}$ pada mandibula dengan pemanfaatan ruang bekas pencabutan gigi 36. Kekurangan ruang pada maksila diperoleh melalui pencabutan gigi 14 dan 25. Perawatan dilakukan dengan alat cekat teknik Begg.

Perawatan teknik Begg dilakukan dalam 3 tahap. Perawatan tahap pertama bertujuan untuk general alignment, leveling dan unraveling, serta koreksi deepbite. Pada tahap ini digunakan archwire 0,014" dengan multiple vertical loop dilengkapi circle hook, anchorage bend $30^{\circ}$, dan elastik intermaksiler klas II 5/16" 2 oz serta open coil untuk distalisasi gigi 25 , 34, 35. Exposure gigi kaninus impaksi dengan closed eruption technique dilakukan secara simultan setelah dilakukan insersi braket sambil menarik gigi kaninus erupsi secara bertahap. Perawatan dilanjutkan dengan penggunaan plain archwire 0,016", disertai anchorage bend $30^{\circ}$, elastik intermaksiler klas II 5/16" 2 oz, dan elastik intramaksiler 1/4" 3 oz untuk koreksi midline dental dan memberi ruang erupsi kaninus sambil dilakukan penarikan gigi kaninus impaksi secara bertahap.

Perawatan tahap kedua bertujuan mempertahankan hasil perawatan tahap pertama dan penutupan sisa ruang pencabutan dengan mesialisasi gigi posterior. Pada tahap ini digunakan plain archwire 0,018", dilengkapi circle hook, anchorage bend $15^{\circ}$, elastik intermaksiler klas II 5/16" 2 oz dan elastik intramaksiler 1/4" 2 oz (konfigurasi $Z$ elastik).

Perawatan tahap ketiga bertujuan mengoreksi inklinasi gigi-gigi anterior dan posterior. Pada tahap ini digunakan plain archwire 0,020", anchorage bend $15^{\circ}$, circle hook pada mesial braket kaninus, uprighting spring, rotating spring, elastik intermaksiler klas II 5/16" 2 oz untuk mempertahankan relasi molar yang telah dicapai, dan cinched back wire di distal molar tube untuk mempertahankan panjang lengkung gigi.

\section{PEMBAHASAN}

Kaninus maksila impaksi dapat terjadi karena riwayat rampan karies pada gigi desidui. Rampan karies menyebabkan lebar mesiodistal gigi desidui berkurang sehingga kemampuannya untuk menyediakan ruang bagi erupsi gigi permanen berkurang dan terjadi defisiensi panjang lengkung maksila. ${ }^{5} \mathrm{Hal}$ ini memungkinkan kaninus maksila yang erupsinya paling akhir, tidak mempunyai 
ruang untuk erupsi. Pada kasus ini posisi kaninus maksila impaksi pada sisi labial ditunjukkan oleh hasil pemeriksaan rontgen Shift sketch. ${ }^{9}$ Perawatan kaninus maksila impaksi dilakukan exposure dengan closed eruption technique kemudian menarik gigi kaninus impaksi secara bertahap dengan mekanika perawatan ortodontik sampai mencapai garis oklusi dan menempati ruang bekas pencabutan premolar pertama kanan maksila (gambar 4). Pada kasus ini dipilih closed eruption technique untuk exposure gigi kaninus impaksi karena diharapkan bagian labial kaninus impaksi akan tertutup gingiva dengan cukup dan baik setelah erupsi penuh dantidak terjadi reintrusi. ${ }^{9}$ Closed eruption technique memberikan sedikit kesulitan apabila braket yang dipasang pada gigi impaksi terlepas sebelum gigi mulai erupsi karena diperlukan pembukaan gingiva lagi. Agenesis pada kasus ini menyebabkan terjadi pergeseran midlinedental dan kesulitan interdigitasi.

Pergeseran midline dental maksila ke kanan dapat terjadi karena adanya kaninus kanan maksila impaksi sedangkan pergeseran midline dental mandibula ke kanan dapat terjadi karena gigi insisivus lateral kanan mandibula agenesis. Koreksi midline dental dan crowding pada maksila dan mandibula dilakukan dengan pencabutan gigi 14 dan 25 serta pemanfaatan bekas pencabutan gigi 36 . Pencabutan gigi 14 dipilih karena akan digantikan oleh kaninus maksila impaksi sedangkan pencabutan gigi 25 dipilih karena kondisi gigi tersebut yang mempunyai tumpatan besar. Koreksi midline pada maksila dilakukan dengan menggeser gigi-gigi 12, 11, 21, 22, 23, dan 24 ke distal.

Perawatan tahap pertama alat cekat sistem Begg bertujuan untuk levelling, unraveling, dan bite opening. ${ }^{14}$ Gigi kaninus maksila impaksi dilakukan exposure secara simultan setelah dilakukan insersi braket kemudian ditarik secara bertahap sehingga mencapai garis oklusi dan menempati posisinya dalam legkung gigi. Pada tahap ini digunakan archwire 0,014" dilengkapi vertical loop, circle hook, anchorage bend $30^{\circ}$, dan elastik intermaksiler klas II 5/16" 2 oz serta open coil untuk distalisasi gigi 24 dan 35 dilanjutkan gigi 34. Pergeseran gigigigi selanjutnya dilakukan menggunakan elastik intramaksiler secara bertahap. Perubahan yang dapat diamati saat ini adalah kaninus maksila impaksi telah menempati posisinya, midline dental

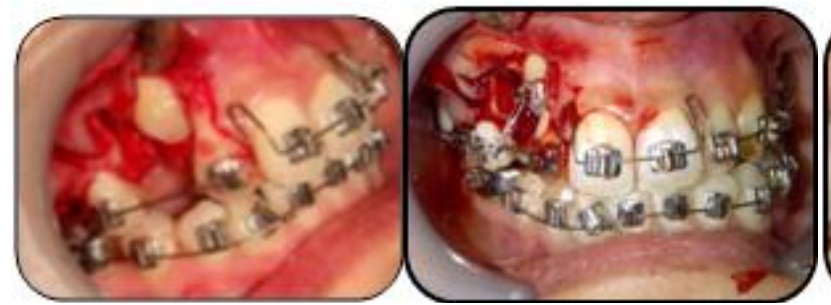

(A)
(B)

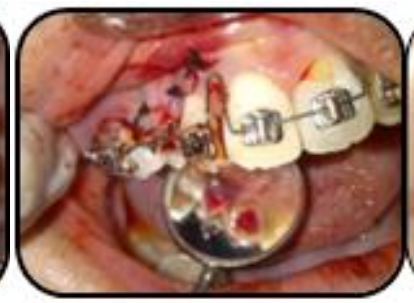

(C)

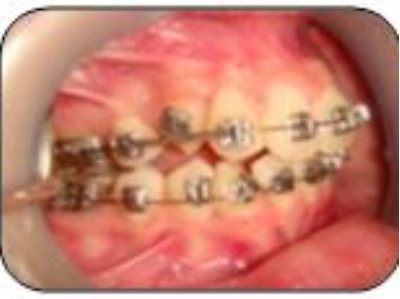

(D)

Gambar 4. (A)-(C) Exposure kaninus dengan closed eruption technique; D. foto intraoral sisi kanan setelah 4 minggu perawatan)
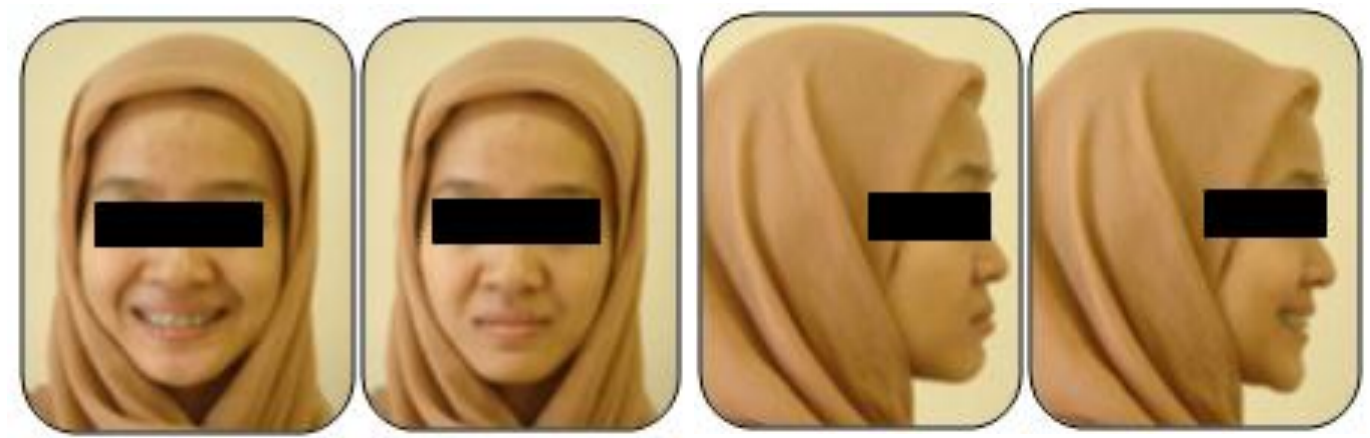

Gambar 5. Foto ekstraoral pasien saat ini 


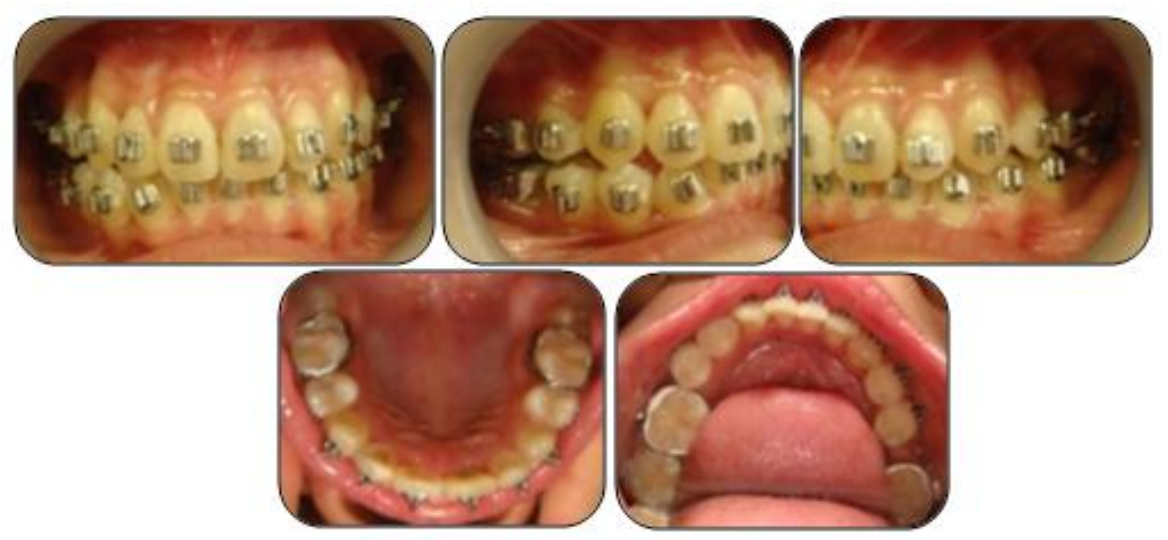

Gambar 6. Foto intraoral pasien setelah 14 bulan perawatan

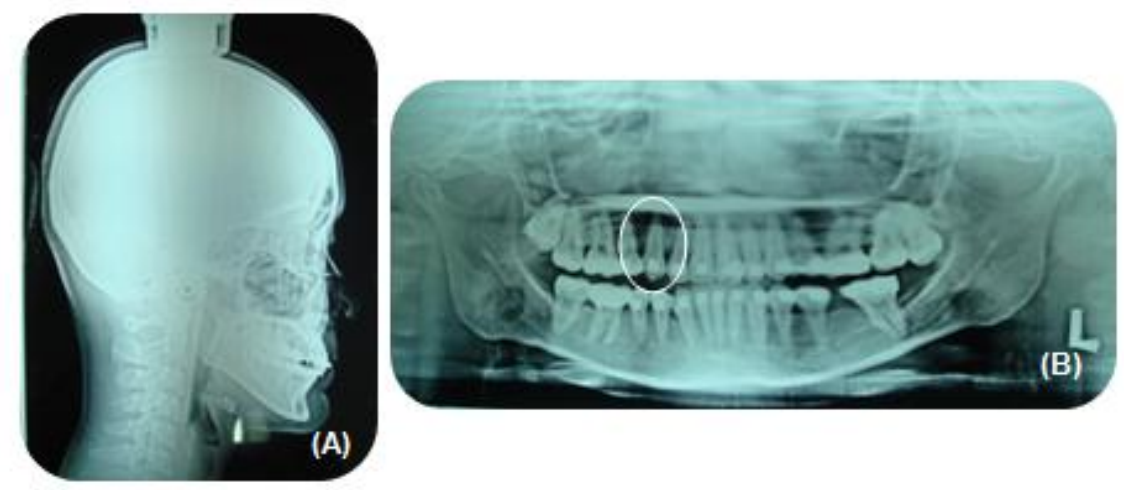

Gambar 7. Radiograf pasien setelah 14 bulan perawatan, A. Sefalogram, B. OPG

maksila, crowding dental maksila dan mandibula telah terkoreksi, overjet $3 \mathrm{~mm}$, dan overbite $3 \mathrm{~mm}$ (gambar 5 dan gambar 6). Keadaan skeletal pasien menunjukkan sedikit perubahan namun masih tetap dalam relasi klas I dengan dental normal (gambar 7 dan table 1). Hal ini sesuai dengan rencana perawatan bahwa tidak dilakukan perubahan skeletal.

Perawatan saat ini dalam tahap memperbaiki posisi kaninus kanan mandibula yang masih rotasi dan memperbaiki interdigitasi gigi-gigi menggunakan plain archwire 0,016" dilengkapi circle hook pada mesial braket kaninus, anchorage bend $15^{\circ}$, elastik intermaksiler klas II 5/16" 2 oz serta uprighting spring dan rotating springuntuk mengoreksi gigigigi yang masih tipping dan rotasi. Perawatan akan dilanjutkan ke tahap kedua untuk menutup sisa ruang bekas pencabutan ggi 36 menggunakan plain archwire 0,018" dilengkapi circle hook, anchorage bend $15^{\circ}$, elastik intermaksiler 5/16" 2 oz, dan elastik intramaksiler $1 / 4 " 3 \mathrm{oz}$.
Tabel 1.Pengukuran sefalometri sebelum perawatan dan selama perawatan.

\begin{tabular}{lccc}
\hline \multicolumn{1}{c}{ Pengukuran } & $\begin{array}{c}\text { Nilai } \\
\text { normal }\end{array}$ & $\begin{array}{c}\text { Sebelum } \\
\text { Perawatan }\end{array}$ & $\begin{array}{c}\text { Selama } \\
\text { Perawatan }\end{array}$ \\
\hline Facial angle & $82^{\circ}-95^{\circ}$ & $88,5^{\circ}$ & $88,5^{\circ}$ \\
Angle of convexcity & $-8,5^{\circ}-9^{\circ}$ & $4^{\circ}$ & $4^{\circ}$ \\
Bidang A-B & $-9^{\circ}-0^{\circ}$ & $-6^{\circ}$ & $-6^{\circ}$ \\
FMPA & $17^{\circ}-28^{\circ}$ & $22^{\circ}$ & $26^{\circ}$ \\
Y-axis & $53^{\circ}-66^{\circ}$ & $61^{\circ}$ & $62^{\circ}$ \\
SNA & $82^{\circ}$ & $85,5^{\circ}$ & $84^{\circ}$ \\
SNB & $80^{\circ}$ & $83^{\circ}$ & $82^{\circ}$ \\
ANB & $2^{\circ}$ & $2,5^{\circ}$ & $2^{\circ}$ \\
GoGn-SN & $32^{\circ}$ & $32^{\circ}$ & $32,5^{\circ}$ \\
Interl-I & $130^{\circ}$ & $139^{\circ}$ & $130^{\circ}$ \\
Sudutl-NA & $22^{\circ}$ & $18^{\circ}$ & $18^{\circ}$ \\
I-NA(mm) & $4 \mathrm{~mm}$ & $5,5 \mathrm{~mm}$ & $5,5 \mathrm{~mm}$ \\
Sudutl-NB & $25^{\circ}$ & $23^{\circ}$ & $21^{\circ}$ \\
I-NB(mm) & $4 \mathrm{~mm}$ & $4 \mathrm{~mm}$ & $4 \mathrm{~mm}$ \\
IMPA & $81,5^{\circ}-97^{\circ}$ & $90^{\circ}$ & $94^{\circ}$ \\
Occ. PI.SN & $14^{\circ}$ & $16^{\circ}$ & $14^{\circ}$ \\
Occ. Pl.FHP & $1,5^{\circ}-14,3^{\circ}$ & $12^{\circ}$ & $10^{\circ}$ \\
Overbite & $2-4 \mathrm{~mm}$ & $5,00 \mathrm{~mm}$ & $3,00 \mathrm{~mm}$ \\
Overjet & $2-4 \mathrm{~mm}$ & $3,00 \mathrm{~mm}$ & $3,00 \mathrm{~mm}$ \\
\hline
\end{tabular}




\section{KESIMPULAN}

Perawataan ortodontik menggunakan teknik Begg yang dilakukan simultan dengan exposurekaninus impaksi labial dengan closed eruption technique dapat memberikan hasil yang memuaskan

\section{DAFTAR PUSTAKA}

1. Kunifec MM. Stability of the impa with reference to the begg method. Angle Orthod. 1971; 41: 264-270.

2. Fletcher GCT. The begg appliance and technique. Briston: John Wright \& Sons (print) Ltd; 1981. H.15-29.

3. Cadman GR. A vade mecum for the begg technique: technical principles. Am.J.Orthod. 1975; 67(5): 477-512.

4. Bhalajhi SI. Orthodontics the art and science. 3rd ed. New Delhi : Arya (MEDI) Publishing House; 2004. H. 392-393.

5. Daskalogiannakois J. Glossary of orthodontic term. Berlin: 2000; H. 224-225.

6. Begg PR, Kesling PC. Begg Orthodontic Theory and Technique. Ed. 2. Philadelphia : W.B. Saunders Co. 1977; p.113-150.
7. Kuftinec MM, Inmam GO. A comparison of plain versus multilooped arch wires in stage I of begg therapy. Am. J. Orthod. 1980; 78 (1): 81-88.

8. Federico VT. Atlas of orthodontic Appliances Fixed and removable. 2th. Ed. 16. Hollywood: Orto cycle Co; 1986.

9. Kokich VG. Surgical and orthodontic management of impacted maxillary canines. Am J Orthod Dentofacial Orthop. 2004; 126: 278-83.

10. Whittington, B and Durward C. Survey of anomalies in primary teeth and their correlation with the permanent dentition. New Zealand Dental J. 1996; 92: 4-8.

11. Olive RJ. Orthodontic treatment of palatally impacted maxillary canines. Aust Orthod J. 2002; 18: 64-70.

12. Graber TM, Vanarsdall RL. Orthodontics, current principles and techniques. $4^{\text {th }}$ ed. St. Louis: Mosby; 2005.

13. Begg PR, Kesling PC. Begg orthodontic theory and technique. $2^{\text {nd }}$ ed. Philadelphia: WB Saunders Co.; 1977.

14. Fletcher GCT. The begg appliance and technique. Briston: John Wright and Sons (print) Ltd.; 1981. 